\title{
Competition issues in European banking
}

\author{
Barbara Casu ${ }^{\dagger}$ \\ Cass Business School, \\ City University London \\ b.casu@city.ac.uk
}

\author{
Claudia Girardone \\ Essex Business School, \\ University of Essex \\ cgirardone@essex.ac.uk
}

\section{Journal of Financial Regulation and Compliance}

(Forthcoming 2009)

\begin{abstract}
Purpose - This paper aims to assess the outcome of EU deregulation and competition policies on the competitive conditions of the main EU banking markets.

Design/methodology/approach -After a review of deregulation and competitition policies in the EU banking industry, we test the degree of competition in the largest five EU banking markets using both structural (concentration ratios and Herfindahl-Hirshman Indices) and non-structural (H-statistics and Lerner Index) approaches.

Findings - Results indicate that EU banking markets are becoming progressively more concentrated and that there is no evidence of an increase in competitive pressure. Country differences are also apparent thereby indicating that despite the sustained regulatory interventions, significant barriers to the integration of EU retail banking markets remain. In line with recent literature our analysis also seems to provide further evidence that concentration is not necessarily a good proxy for competition.

Originality/value - Increased market concentration and its effects on competition are of relevance in a period of renewed EU regulatory efforts to remove the remaining barriers to the integration of financial markets. The evaluation of competitive conditions and market power in EU banking are therefore of interest to policy-makers and regulators.
\end{abstract}

Keywords: Competition Policy; European Banking; Regulation; Concentration; Market Structure.

Paper type: Research paper

\footnotetext{
$\dagger$ Faculty of Finance, Cass Business School, City University, 106 Bunhill Row, London EC1Y 8TZ, UK. Tel. +44 (0) 2070405283 or email: b.casu@city.ac.uk

$\$$ Essex Business School, University of Essex, Wivenhoe Park, Colchester, CO4 3SQ. Tel. +44(0) 120687 4156 or email: cgirardone@essex.ac.uk
} 


\section{Introduction}

Competition is generally considered a positive force in most industries; it is supposed to have a positive impact on an industry's efficiency, quality of provision, innovation and international competitiveness. However, this issue has always been controversial in banking, as the perceived benefits derived from increased competition have to be weighted against the risks of potential instability. As a consequence, the banking industry has been historically heavily regulated. Furthermore, the existence of frictions in banking markets (for example, entry barriers and asymmetric information), cause the welfare theorems associated with perfect competition not to be directly applicable and allow room for the exercise of market power (Vives, 2001). Nevertheless, a healthy degree of rivalry is considered necessary for the dynamic efficiency of an industry and this principle is at the basis of the trend towards fostering greater competition in banking markets all over the world.

In the European Union (EU) in particular, the past twenty years saw substantial deregulation of financial services, together with the establishment of the Economic and Monetary Union (EMU) and the introduction of the euro. These changes were aimed at fostering integration, removing entry barriers and promoting both competition and efficiency in the EU banking industry. However, several studies (ECB, 2008) have highlighted that the progress of the Single Market in financial services has been slow, particularly in the retail sector, and this calls into question the competitive conditions of EU banking markets. The European Commission (EC) is in charge of competition policy at the EU level, particularly in the areas of antitrust, cartels, mergers and acquisitions and the granting of state aid to financial institutions. Despite several landmark decisions in recent years, the task of the EC's direct involvement in fostering competition is now constrained by the need of finding solutions to the current financial crisis. The presence of a possible trade-off between competition and stability has always played an important role at a policy level and gained even more prominence in light of recent events. Questions remain as to whether a certain degree of market power would be beneficial in banking to provide incentives for banks to undertake less risky strategies. In this context, the evaluation of competitive conditions and market power becomes increasingly 
important for policy-makers and regulators. Competition authorities often rely on the validity of the structure- conduct-performance (SCP) paradigm and proxy competition with measures of market concentration, such as the Herfindahl-Hirshman Index (HHI). On the other hand, recent academic studies have shown concentration to be a poor proxy for competition. In this paper, we review the different methods proposed in the academic literature to assess the competitive conditions of banking markets. We then present the results of an empirical analysis of the dynamics of competition in EU banking markets since the year 2000. Concentrating on the commercial banking sector of the five largest EU banking markets (France, Germany, Italy, Spain and the UK), we test the degree of competition by using both structural (concentration ratios, HHI) and non-structural methods (the Panzar-Rosse H-statistic and the Lerner index).

The remainder of the paper is organised as follows: Section 2 reviews the main regulatory changes that aimed at fostering integration and competition in the EU. Section 3 briefly illustrates the design of competition policy at the EU level. Section 4 discusses the measurement of competition in the banking industry whereas Section 5 presents the results of the empirical analysis. Section 6 concludes.

\section{Deregulation policies and competition in the EU banking markets}

At the beginning of the 1990s it was a widespread belief that the banking sector in Europe would enter a period of increased competition: the advent of the EMU and the introduction of the Euro in 1999 were expected to reinforce the pressure for the reduction of existing excess capacity and lead to increased internationalisation and geographical diversification, as well as to increased conglomeration and mergers and acquisitions.

Regulatory developments have been an important factor shaping the structure of European banking markets. From 1 January 1993 the European legislation (Maastricht Treaty) created the 'largest and most open banking market in the world', by eliminating or lessening existing barriers and by introducing the single EU market for financial services. A number of studies have tried to estimate the potential welfare gains resulting from the completion of the single market. The Cecchini/Price Waterhouse (1988) study 
was the first to analyse comparative competitive conditions across EU banking and financial systems. Their main assumption was that the single market would induce a series of integration effects that would promote the efficiency and competitiveness of EU firms through two channels: increased market size and heightened levels of competition. Twenty years after the publication of the Cecchini/Price Waterhouse findings, a number of studies have attempted to assess the impact of the EU regulatory intervention on banking sectors. Recent empirical evidence suggests that the sustained legislative changes at the EU level, have contributed towards the integration of European banking and financial markets (Goddard et al., 2007). There is some evidence of integration in money, bond and equity markets (Baele et al., 2004) and in wholesale banking (Cabral et al., 2002). However, most empirical studies suggest that significant barriers to the integration of retail banking markets still exist (Berger et al., 2001 and 2003).

One of the effects of the regulatory changes (see Table 1) was to spur a trend towards consolidation, resulting in the recent wave of mergers and acquisitions. From a policy point of view, it is difficult to know what impact these structural developments are likely to have on the competitive environment and how they may influence the efficiency and stability of banking markets. On the one hand, increased concentration is expected to intensify market power and therefore hinder competition. On the other hand, it might be argued that if bank mergers and acquisitions are driven by economies of scale, then increased concentration may foster efficiency improvements. This indicates the importance of the assessment of competition in the industry, as well as the policies relevant to its maintenance. The issue concerning increased market concentration and its effect on competition and, indirectly, stability of the EU banking sector is of relevance in a period of renewed regulatory efforts to remove the remaining barriers and of increased domestic and cross border M\&As.

<Insert Table 1 about here>

Despite the mixed outcomes of EU regulatory changes fostering competition is still high on the policy agenda. The European Commission, in its recent White Paper on Financial Services Policy (2005-2010) has stated that its principal objectives include: "To 
consolidate dynamically towards an integrated, open, inclusive, competitive, and economically efficient EU financial market and to remove the remaining economically significant barriers so financial services can be provided and capital can circulate freely throughout the EU at the lowest possible cost..." (SEC(2005) 1574).

Within the European Commission, the competition department works to enhance competition in EU banking, insurance and securities markets. As stated in the White Paper (2005-2010), the aim of the Commission's competition policy is to "use competition pro-actively to indentify and help tackle barriers in the Single Market".

\section{Competition policy in the EU banking sector}

In general terms, competition policy means "applying rules to make sure that companies compete with each other and, in order to sell their products, innovate and offer good prices to consumers" (Todd, 2007). The current unified competition policy at the EU level (with the Commission as chief enforcer) is based on the 2004 Commission reform on merger control (the 'EC Merger Regulation' [1]) that intended to provide a "level playing field" in a "one-stop shop" [2] for the examination of mergers with a "community dimension". According to this legislation, operations which would significantly impede effective competition, in particular as a result of the creation or strengthening of a dominant position, would be declared incompatible with the common market. For operations below specific thresholds of turnover and sales, it is usually the national competition authorities in the EU member states to review the case and enforce competition policy [3].

In recent years, the role of the competition department within the European Commission has evolved to become increasingly 'pro-active': the Commission has carried out specific inquiries in sectors that are still characterised by high barriers to competition. For example, in 2007 an inquiry on the retail banking sector [4] highlighted a number of concerns, particularly in the European payments cards industry and credit database.

The application of competition policy typically relates to: a) mergers, b) cartels, c) abuse of dominant position (antitrust) and d) state aid. Regulatory concerns over mergers and 
cartels have always played an important role in the EU. In the light of recent market developments, state aid is becoming an increasingly topical issue.

\section{a. Domestic and Cross-Border Mergers}

By creating or strengthening a dominant player, the outcome of a merger may result in reduced competition, which may harm consumers through higher prices, reduced choice or decreased innovation. The objective of the competition department is to examine proposed mergers and to prevent harmful effects to consumers. Mergers are examined at the EU level if they go beyond the national borders of a member state or if the combined entity exceeds a specified threshold in terms of global and European sales. If these conditions are not met, then the national competition authorities in each member state are responsible to review the merger.

Only a handful of domestic mergers have been blocked by the national authorities. One example is that of the merger between Lloyds TSB and Abbey National that was prohibited by the UK competition commission in 2001.

Cross-border operations, on the other hand, are less likely to be perceived as having substantial anti-competitive consequences. However, evidence has shown that often member states abuse the EC Merger Regulation to protect their national interests. In 1999, the Portuguese authorities blocked the proposed takeover by BSCH (Banco Santander Central Hispano) of Portuguese group Champalimaud. In 2005, the former Governor of the Bank of Italy, Mr Fazio, was alleged to have favoured BPI (Banca Popolare Italiana)'s bid to buy another Italian bank, Banca Antoniana Popolare Veneta (Antonveneta), over ABN AMRO's offer. These cases of apparent "misuse of supervisory power", as defined by the Commission, have resulted in the acknowledgement of a complementary objective for competition policy, in the form of limitation of the discretion and powers of national supervisors (see also Carletti et al. 2007). The new directive that resulted ("the Qualifying Holdings Directive") is due for implementation in March 2009. Although it represents a significant step towards ensuring greater transparency and legal certainty in the supervisory control, it still has some 
pitfalls, particularly in the form of lack of transparency and excessive discretion of the supervisory authorities (Carletti and Vives, 2008).

\section{b. Cartels}

An important role in the application of competition policy is played by cartels. A cartel is defined as a group of similar, independent firms which collude to pursue price fixing, to limit production or to share markets or customers between them. Cartels are illegal under EU competition law. Action against cartels is a type of antitrust enforcement. Evidence of cartels is not easy to find. In 2001 eight Austrian banks were fined over $€ 120$ million by the Commission (OJ L 56, 24.02.2004) for their participation in a wide-ranging price cartel known as "the Lombard Club". The cartel started well before the accession of Austria into the EU so for many years was used to fix deposit, lending and other rates in the entire Austrian territory. More recently the Commission fined Visa, a company that operates a large electronic payment network, for refusing to admit Morgan Stanley as a member of the card and payment systems between 2000 and 2006. The Commission found that Visa's unjustified and discriminatory behaviour restricted competition in the provision of credit card acceptance services to merchants in the UK. The decision was also taken in line with the objectives of constructing a Single Euro Payments Area (SEPA).

\section{c. Abuse of dominant position}

According to the EC merger law, abuse of dominant position refers to predatory pricing aimed at eliminating competition in the market. The only recent case was in 2004, when the Commission found Clearstream Banking AG and its parent Clearstream International SA responsible for infringing competition rules. For about two years these banks refused to supply cross-border clearing and settlement services for registered shares issued under German law. Moreover, they were found responsible for applying discriminatory prices between January 1997 and January 2002, to the detriment of Euroclear Bank SA, a German bank. 


\section{d. State aid}

Finally, the Commission controls whether government intervention or state aid causes any distortion in competition and intra-community trade by providing an unfair advantage to specific firms. As pointed out by Carletti and Vives (2008), this area is particularly relevant for the banking sector because of the availability of a lender of last resort. Besides, the events associated with the current financial and banking crisis make it a topical issue. A temporary framework has currently been adopted by the Commission to give member states "the opportunity to tackle the effects of credit squeeze on the real economy". Indeed, although the literature is increasingly pro-competition, recent events have shown that mergers can be allowed for the sake of stability. Recent UK cases are the acquisition of the mortgage bank Bradford \& Bingley by Abbey National in December 2008 and the creation of the retail banking giant Lloyds group resulting from the merger between Lloyds TSB and HBOS in January 2009. Both operations were cleared under EU Merger Regulation and the EC treaty of state aid rules. These are examples of exceptional measures taken to rescue two ailing institutions (Bradford \& Bingley and HBOS) in the context of the current financial crisis.

\section{The measurement of competition in the EU banking industry}

In recent years, the EU authorities' competitive analysis has mainly focused on the assessment of horizontal mergers. A set of guidelines (OJ 2004/C 31/03) complement the 2004 EC Merger Regulation and clarify the Commission's approach to appraise concentration within the scope of the Merger Regulation. The 'test' is to assess whether a merger "significantly impede effective competition, in particular as a result of the creation or strengthening of a dominant position in the common market or a substantial part of it" (Art. 1). The guidelines also clarify the Commission's interest in evaluating market shares and concentration levels because "they provide useful first indications of the market structure and of the competitive importance of both the merging parties and their competitors" (Art. 14). Specifically, the Commission first defines the relevant geographic and product markets and then applies the market share and HHI rules, as illustrated in Table 2. 
<Insert Table 2 about here>

Table 2 essentially shows that post-merger entities that are presumed to obtain large or very large market shares and HHI are considered a real competitive concern by the Commission. These simple measures of market structure are often used by competition authorities all over the world, including the US Federal and Trade Commission and the Department of Justice.

The approximate 'rules' reported in Table 2 clearly suggest that the authorities assume a negative (positive) correlation between market concentration and competition (market power). In other words (although a relationship with profits is not tested) they assume the validity of the traditional industrial organization theory known as structure conductperformance (Bain, 1951). This theory has been challenged in the literature because it does not measure competition but it is based on the assumption that concentration weakens competition by fostering collusion among firms and ignores the argument that firms maybe more profitable because of greater efficiency [5].

Dick and Hannan (2008) make two sets of observations: first, that the simple "HHI rule" is used as a way to easily identify the cases that need further and more comprehensive scrutiny. Second, they claim that one possible reason of the use of unsophisticated methods in competition analysis on the part of the authorities is associated with industryspecific issues. Namely, it relates to the difficulties arising in the definition of inputs and outputs for banks. Finally, other possible reasons include for instance, the presence of high switching costs in banking; and the difficulties in defining the geographic markets and relevant consumers.

Recent academic works seems to favour the so-called non-structural approaches to bank competition developed in the context of the New Empirical Industrial Organisation (NEIO) literature. They posit that factors other than market structure and concentration may affect competitive behaviour, such as entry/exit barriers and the general contestability of the market (Baumol et al. 1982; Bresnahan, 1989; Panzar and Rosse, 1987). Moreover, differently from structural methods, the competitive environment is not implied but is usually measured, as with the price mark-ups approach (the Lerner index 
of monopoly power and conjectural variations models) and the correlations of input costs with output prices (the Panzar-Rosse H-statistic).

Probably the most important advantage of non-structural approaches is that they do not assume a priori that concentrated markets are not competitive because contestability may depend on the extent of potential competition (see also Goddard et al., 2001: 81) and not necessarily on market structure. Another advantage of non-structural models is that there is no need to specify a geographic market, since the behaviour of individual banks gives an indication of their market power.

\section{Competition patterns in European banking}

The following sections present the results of the analysis of competitive conditions in the largest five EU banking markets since the year 2000. Focusing on the commercial banking sector of France, Germany, Italy, Spain and the UK, we test the degree of competition by using both structural (concentration ratios, Herfindhal Hirshman Indices) and non-structural methods (the Panzar-Rosse H-statistic and the Lerner index. The data are derived from BankScope, a global database published by Bureau Van Dijk [6]. We restricted the investigation to commercial banks as there are still significant differences in the retail market structure among EU member states and in some countries the saving banks sector is still partially benefiting from state help [7].

\subsection{Process of consolidation in the EU banking sector}

Since the year 2000, the aggregate number of credit institutions in the EU declined sharply in most countries. At the end of 2005, there were 8,684 institutions representing a decrease of $10.9 \%$ relative to 2001 . Consolidation has proceeded even faster in the euro area with a decrease of $12.5 \%$ since 2001 (ECB, 2006). Until recently, concentration operations in the EU banking sector have been predominantly of a domestic nature. Between 1993 and 2003, the number of M\&As involving domestic credit institutions represented about $80 \%$ of total consolidation activity in the EU (Walkner and Raes, 2005). However, the pace of domestic consolidation has recently slowed down, whereas the value of cross-border bank M\&As has been rising, reaching record levels in 2005 . 
EU-wide consolidation has been under way for some time: for example, HSBC and Credit Commercial de France (2000); Banco Santander's acquisition of Abbey (2004); Unicredit's acquisition of HVB (2005); BNP Paribas and Banca Nazionale del Lavoro (2006); and the acquisition of ABN AMRO by the consortium lead by the Royal Bank of Scotland (2007).

Table 3 shows the means of the structural indicators of market concentration across our sample of EU countries for all banks over the period 2000-2005. The HerfindahlHirshman Index (HHI) represents the market share in terms of total assets of every bank in the market whereas the CR-5 indicates the market share of the five largest banks.

<Insert Table 3 about here>

The degree of concentration of the EU banking system continued to rise; in the period 2000-2005 the five largest credit institutions increased their share of total assets from $37.8 \%$ to $42.3 \%$ (from $39.1 \%$ to $43 \%$ in the euro area) (ECB, 2006). Against the EU average (in 2005, HHI was 601 and CR-5 was $43 \%$ for the EU-25), concentration levels remain relatively low in Germany, Italy and the UK. With the only exception of Spain, the structural measures of concentration have increased significantly in all countries in our sample. In the UK alone, in the six years period from 2000 concentration (measured as CR-5) increased by $28.57 \%$.

We also calculated the HHI for the sub-sample of commercial banks on total assets. Again, the data show that national conditions still vary considerably across countries (see Figure 1) and this is reflected in the different market structures of the retail banking industry in general and of the commercial banking industry in particular. Most countries, however, experienced an increase in concentration during the period of analysis and this might be also reflected in their measures of competition and market power.

$<$ Insert Figure 1 about here> 


\subsection{Competition patterns in European banking: H-statistic and Lerner index}

Following the established empirical literature, we estimate competition in the five EU banking markets using the Panzar-Rosse H-statistic and the Lerner index.

The Lerner index (Lerner, 1934) is an indicator of the degree of market power and it is a well established measure of competition in the banking literature. It represents the extent to which market power allows firms to fix a price $(p)$ above marginal cost $(m c)$ [8]. The Lerner index is defined as $(p-m c) / p$; a value of the index equal to zero indicates perfect competition, while a value of one indicates monopoly.

The H-statistics, on the other hand, is an indicator of the degree of market competition developed in the context of the NEIO (Panzar and Rosse, 1987). The H-statistic exploits the relationship between input prices and equilibrium revenues and it is calculated using a reduced form revenue equation that measures the sum of elasticities of total revenues with respect to the firm's input prices. It is based on the premise that monopoly theory implies that the revenue of a monopolist falls as marginal cost rises and therefore the $\mathrm{H}$ statistics is interpreted as follows: $H$ is equal to zero or negative when the competitive structure is a monopoly or a perfectly colluding oligopoly. When $\mathrm{H}$ is equal to 1 , it indicates perfect competition; and $0<\mathrm{H}<1$ indicates monopolistic competition. $H$ can be interpreted as a continuous measure of the level of competition, in particular between 0 and 1 , in the sense that higher values of $H$ indicate stronger competition than lower values [9].

Table 4 shows the evolution of marginal costs and of the Lerner index over the sample period. Measuring market power is fundamental to the analysis of bank competition: the lower the competition faced by a bank (or any other firm), the greater its market power, reflected by its ability to set price above marginal costs.

<Insert Table 4 about here>

Marginal costs decreased in all countries over the sample period, showing an increase in 2005. Italy and Spain, which display the highest average marginal costs, also display the biggest decrease, possibly because of the reduction of both financial and operating costs. Despite the decrease in marginal costs, Italy and Spain report the highest increase in the 
Lerner index, thereby indicating that the decrease in marginal cost was smaller than the decrease in the average price of assets. On average, banks seem to have reduced their $m c$ faster than price falls; this will increase the Lerner index thus suggesting greater market power and less competition. In all countries (apart from the UK) the Lerner index is higher in 2004 than in 2000, thus suggesting less competitive conditions.

\section{<Insert Table 5 about here>}

Table 5 reports the estimated H-statistics: results indicate monopolistic competition in all countries [10] and ranges from 0.3715 in France to 0.7783 in Germany [11]. Therefore, competition in the commercial banking sector seems the highest in Germany, Spain and the UK, followed by Italy and France. These results are consistent with the current literature, which finds monopolistic competition to be the prevalent market structure in European countries [12]. To validate our results, we conducted the equilibrium test for all the banking markets and found that the banking systems were in long-run equilibrium in the period of study [13].

Overall, the empirical analysis has highlighted that the main EU banking markets are becoming progressively more concentrated and that there is no evidence of an increase of competitive pressure over the period. Further, country differences are also apparent thereby indicating that despite the sustained regulatory intervention in the EU banking markets, significant barriers to the integration of retail banking markets still exist.

The empirical analysis seems to provide further evidence that concentration is not necessarily a good proxy for competition. Indeed, one of the least concentrated banking markets in the EU is Italy; however both the Lerner index and H-statistic estimation indicate low competitive conditions. 


\section{Conclusions}

Over the past twenty years, the deregulation and market integration processes have been a steady feature of EU banking markets and have given way to profound transformations and restructuring, which materialised in enhanced consolidation. The issue concerning increased market concentration, its effect on competition and, indirectly, stability of the EU banking sector is of relevance in a period of renewed regulatory efforts to remove the remaining barriers and of increased domestic and cross- border M\&As. The White Paper (2005-2010) declared the aim of the Commission's competition policy to "use competition pro-actively to identify and help tackle barriers in the Single Market". However, our empirical analysis has highlighted significant country differences, thereby indicating that despite the sustained regulatory intervention, substantial barriers to the integration of retail banking markets still exist. Further, results show that the main EU banking markets are becoming progressively more concentrated and that there is no evidence of an increase in competitive pressure over the period. The EU Commission, as well as national competition authorities typically rely on market share and concentration levels to infer competitive conditions (the 'HHI rule'). However our empirical analysis, in line with recent literature, seems to provide further evidence that concentration is not necessarily a good proxy for competition. 


\section{References}

Angelini, P., Cetorelli, N. (2003), "The effects of regulatory reform on competition in the banking industry", Journal of Money, Credit and Banking, Vol. 35 No. 5, pp. 663684.

Baele, L.M., Ferrando, A, Hordahl, P., Krylova, E. and Monnet, C. (2004), "Measuring financial integration in the euro area”, ECB Occasional Paper No. 14.

Bain, J.S. (1951), "Relation of profit rate to industry concentration”, Quarterly Journal of Economics, Vol. 65 No. 3, pp. 293-324.

Baumol, W.J., Panzar, J. C. and Willig, R.D. (1982), Contestable Markets and the Theory of Industry Structure, Harcourt Brace Jovanovich, San Diego.

Berg, S.A. and Kim, M. (1994), "Oligopolistic interdependence and the structure of production in banking: An empirical evaluation”, Journal of Money, Credit, and Banking, Vol. 26 No .2, pp. 309-322.

Berger, A.N., De Young, R. and Udell, G. (2001), "Efficiency barriers to the consolidation of the European financial services industry", European Financial Management, Vol. 7 No. 1, pp. 117-130.

Berger, A.N. (1995), “The profit-structure relationship in banking: Tests of market-power and efficient-structure hypotheses", Journal of Money, Credit, and Banking, Vol. 27 No. 2, pp. 404-431.

Berger, A.N., Dai, Q., Ongena, S. and Smith, D.C. (2003), "To what extent will the banking industry be globalized? A study of bank nationality and reach in 20 European nations", Journal of Banking and Finance, Vol. 27 No. 3, pp. 383-415.

Bikker, J.A. and Haaf, K. (2002), “Competition, concentration and their relationship: An empirical analysis of the banking industry", Journal of Banking and Finance, Vol. 26, pp. 2191-2214.

Bresnahan, T.F. (1989), "Empirical studies of industries with market power", in: Schmalensee, R. and Willig, R.D. (Eds.), Handbook of Industrial Organisation, vol. II. Elsevier, Amsterdam, pp. 1012-1055.

Cabral, I., Dierick, F. and Vesala, J. (2002), "Banking integration in the euro area", ECB Occasional Paper Series 6. 
Carletti, E. and Vives, X. (2008), "Regulation and competition policy in the banking sector”, IESE Business School Occasional Paper No. 159, August.

Carletti, E., Hartmann, P. and Ongena, S. (2007), "The economic impact of merger control: what is special about banking?”, ECB Working Paper No. 786, Frankfurt.

Casu, B., Girardone, C. and Molyneux, P. (2006), Introduction to banking, Harlow, Pearson Education.

Casu, B. and Girardone, C. (2006), "Bank competition, concentration and efficiency in the single European market", The Manchester School, Vol. 74 No. 4, pp. 441468.

Cecchini, P. (1988), The European challenge, 1992: The benefits of a single market, Wilwood House, England.

Claessens, S. and Laeven, L. (2004), "What drives bank competition? Some international evidence”, Journal of Money, Credit, and Banking, Vol. 36 No. 2, pp. 563-584.

De Bandt, O. and Davis, E.P. (2000), "Competition, contestability and market structure in European banking sectors on the eve of EMU", Journal of Banking and Finance, Vol. 24 No. 6, pp. 1045-1066.

Demsetz, H. (1973), "Industry structure, market rivalry and public policy", Journal of Law and Economics, Vol. 16 No. 1, pp. 1-10.

Dick, A. and Hannan, T.H. (2009), "Competition and antitrust policy in EU banking”, in Berger, A.N., Molyneux, P. and Wilson, J.O.S. (Eds), The Oxford Handbook of Banking, Oxford University Press, forthcoming July 2009.

ECB (2008), "Financial integration in Europe", Frankfurt, April.

European Central Bank (2006), "EU banking structures”, Frankfurt, October.

Evanoff, D.D. and Fortier, D.L. (1988), "Re-evaluation of the structure conduct performance paradigm in banking”, Journal of Financial Services Research, Vol. 1 No. 3, pp. 277-294.

Fernandez de Guevara J., Maudos, J. and Perez, F. (2005), "Market power in European banking sector", Journal of Financial Services Research, Vol. 27 No. 2, pp. 109137.

Goddard, J.A., Molyneux, P. and Wilson, J.O.S. (2001), European banking. Efficiency, technology and growth, John Wiley and Sons, England. 
Goddard, J.A., Molyneux, P., Wilson, J.O.S. and Tavakoli, M. (2007), "European banking: An overview", Journal of Banking and Finance, Vol. 31 No. 7, pp. 1911-1935.

Lerner, A.P. (1934), "The concept of monopoly and the measurement of monopoly power", Review of Economic Studies, Vol. 1 No. 3, pp. 157-175.

Molyneux, P., Lloyd-Williams, D.M. and Thornton, J. (1994), "Competitive conditions in European banking", Journal of Banking and Finance, Vol. 18 No. 3, pp. 445-459

Panzar, J.C. and Rosse, J.N. (1987), "Testing for monopoly equilibrium”, Journal of Industrial Economics, Vol. 35 No. 4, pp. 443-456.

Shaffer, S. (1982) "Non-structural test for competition in financial markets", in "Bank Structure and Competition", Conference Proceedings, Federal Reserve Bank of Chicago, pp. 225-243.

Shaffer, S. (1993), "A Test of competition in Canadian banking", Journal of Money, Credit and Banking, Vol. 25 No. 1, pp. 49-61.

Smirlock, M. (1985), "Evidence on the (non) relationship between concentration and profitability", Journal of Money, Credit and Banking, Vol. 17 No. 1, pp. 69-83.

Todd, J. (2007), Transcript from an interview on BBC World, September.

Vives, X. (2001), "Competition in the changing world of banking", Oxford Review of Economic Policy, Vol. 17 No. 4, pp. 535-547.

Walkner, C. and Raes, J.P. (2005), "Integration and consolidation in EU banking: An unfinished business", European Commission, DG Economics and Financial Affairs, Economic Papers No. 226, April. 
Table 1

Selected regulatory measures impacting on the EU banking and financial sectors

\begin{tabular}{|l|l|}
\hline Year & Regulation \\
\hline 1977 & First Banking Directive \\
\hline 1988 & Basle Capital Adequacy Regulation \\
\hline 1988 & $\begin{array}{l}\text { Deregulation of Capital Movements in the European Monetary System } \\
\text { EMS })\end{array}$ \\
\hline 1989 & Second Banking Directive \\
\hline 1993 & Investment Services Directive \\
\hline 1999 & Financial Services Action Plan (FSAP) \\
\hline 2000 & Directive on e-money \\
\hline 2001 & Directive on the Reorganisation and Winding-Up of Credit Institutions \\
\hline 2001 & Regulation on the European Company Statute \\
\hline 2004 & New EU Takeover Directive \\
\hline 2005 & White Paper on Financial Services Policy \\
\hline 2007 & Capital Requirement Directive (Basle II) \\
\hline 2007 & Markets in Financial Instrument Directive (MiFID) \\
\hline
\end{tabular}

Source: Adapted from Casu, Girardone and Molyneux (2006). 
Table 2

Market share and concentration levels used by the European Commission in competitive analysis

\begin{tabular}{|c|c|c|}
\hline \multirow{2}{*}{ Indicators } & \multicolumn{2}{|c|}{ Approximate rules } \\
\hline & $\begin{array}{l}\text { Evidence of a } \\
\text { dominant position in } \\
\text { the common market }\end{array}$ & $\begin{array}{l}\text { Absence of } \\
\text { competition concerns }\end{array}$ \\
\hline $\begin{array}{l}\text { Current market share } \alpha_{i} \text { of the } \\
\text { post-merger bank }\end{array}$ & $\begin{array}{l}\text { - Typically very large } \\
\text { market share } \geq 50 \% \\
\text { - Several cases when } \\
\text { market share between } \\
40-50 \% \\
\text { - Some cases when } \\
\text { market share is } \leq 40 \%\end{array}$ & - Market share $\leq 25 \%$ \\
\hline $\begin{array}{l}\text { Herfindahl-Hirschman Index } \\
\text { (HHI) of the post-merger bank } \\
\text { calculated as the sum of squared } \\
\text { market shares of all banks in the } \\
\text { market: : } \sum_{i=1}^{n} \alpha_{i}^{2}\end{array}$ & $\begin{array}{l}-\mathrm{HHI}>2000 \text { and } \\
\Delta \mathrm{HHI}<150\end{array}$ & $\begin{array}{l}-\mathrm{HHI}<1000 \\
-1000<\mathrm{HHI}<2000 \text { and } \\
\Delta \mathrm{HHI}<250 \text { with some } \\
\text { exceptions (see Art. 20) }\end{array}$ \\
\hline $\begin{array}{l}\text { Change in HHI is a proxy for the } \\
\text { change in concentration directly } \\
\text { brought about by the merger } \\
\Delta \sum_{i=1}^{n} \alpha_{i}^{2}=\Delta H H I\end{array}$ & & \\
\hline
\end{tabular}

Source: Adapted from OJ 2004/C 31/03. 
Table 3

Concentration Measures: HHI and CR-5 (all banks, by total assets)

\begin{tabular}{|l|rrrrrrr|}
\hline & 2000 & 2001 & 2002 & 2003 & 2004 & 2005 & $2000-2005$ \\
\hline Herfindahl-Hirshman Index & & & & & & & \\
France & 587 & 606 & 551 & 597 & 623 & 758 & $29.13 \%$ \\
Germany & 151 & 158 & 163 & 173 & 178 & 174 & $15.23 \%$ \\
Italy & 190 & 260 & 270 & 240 & 230 & 230 & $21.05 \%$ \\
Spain & 581 & 532 & 513 & 506 & 482 & 487 & $-16.18 \%$ \\
United Kingdom & 264 & 282 & 307 & 347 & 376 & 399 & $51.14 \%$ \\
CR-5 & & & & & & & \\
France & & & & & & & \\
Germany & 47 & 47 & 45 & 47 & 50 & 53 & $12.77 \%$ \\
Italy & 20 & 20 & 21 & 22 & 22 & 22 & $10.00 \%$ \\
Spain & 23 & 29 & 31 & 28 & 26 & 27 & $17.39 \%$ \\
United Kingdom & 46 & 44 & 44 & 43 & 42 & 42 & $-8.70 \%$ \\
\hline & 28 & 29 & 30 & 33 & 35 & 36 & $28.57 \%$ \\
\hline
\end{tabular}

Source: ECB (2006) and Casu et al. (2006). 


\section{Table 4}

Marginal costs and the Lerner index of monopoly power

\begin{tabular}{|l|l|l|l|l|l|l|l|l|l|l|}
\hline Countries & \multicolumn{3}{|c|}{ France } & \multicolumn{2}{c|}{ Germany } & \multicolumn{2}{c|}{ Spain } & \multicolumn{2}{c|}{ UK } \\
\cline { 2 - 13 } Years & $\begin{array}{c}\text { Marginal } \\
\text { Cost }\end{array}$ & $\begin{array}{c}\text { Lerner } \\
\text { index }\end{array}$ & $\begin{array}{c}\text { Marginal } \\
\text { Cost }\end{array}$ & $\begin{array}{c}\text { Lerner } \\
\text { index }\end{array}$ & $\begin{array}{c}\text { Marginal } \\
\text { Cost }\end{array}$ & $\begin{array}{c}\text { Lerner } \\
\text { index }\end{array}$ & $\begin{array}{c}\text { Marginal } \\
\text { Cost }\end{array}$ & $\begin{array}{c}\text { Lerner } \\
\text { index }\end{array}$ & $\begin{array}{c}\text { Marginal } \\
\text { Cost }\end{array}$ & $\begin{array}{c}\text { Lerner } \\
\text { index }\end{array}$ \\
\hline 2000 & 0.563 & 0.139 & 0.479 & 0.229 & 0.629 & 0.017 & 0.619 & 0.009 & 0.548 & 0.197 \\
\hline 2001 & 0.549 & 0.153 & 0.479 & 0.221 & 0.617 & 0.034 & 0.596 & 0.043 & 0.543 & 0.188 \\
\hline 2002 & 0.563 & 0.117 & 0.462 & 0.232 & 0.555 & 0.104 & 0.586 & 0.028 & 0.503 & 0.210 \\
\hline 2003 & 0.534 & 0.156 & 0.449 & 0.246 & 0.548 & 0.125 & 0.538 & 0.059 & 0.471 & 0.190 \\
\hline 2004 & 0.513 & 0.190 & 0.447 & 0.242 & 0.540 & 0.144 & 0.542 & 0.066 & 0.502 & 0.181 \\
\hline 2005 & 0.577 & 0.089 & 0.454 & 0.230 & 0.580 & 0.085 & 0.589 & 0.071 & 0.537 & 0.148 \\
\hline
\end{tabular}

Note: LERNER=0 indicates perfect competition; LERNER=1 indicates monopoly. 
Table 5

H-statistics Results

\begin{tabular}{|c|ccccc|}
\hline & FRANCE & GERMANY & ITALY & SPAIN & UK \\
\hline H statistic & $0.3715^{* * *}$ & $0.7783^{* * *}$ & $0.5395^{* * * *}$ & $0.7359^{* * *}$ & 0.7433 \\
F test & & & & & \\
(Hstat=0) & 119.14 & 331.25 & 389.33 & 197.35 & 355.90 \\
Prob>F & 0.0000 & 0.0000 & 0.0000 & 0.0000 & 0.0000 \\
F test & 340.96 & 26.89 & 283.56 & 25.43 & 42.43 \\
(Hstat=1) & 0.0000 & 0.0000 & 0.0000 & 0.0000 & 0.0000 \\
Prob>F & & Yes & Yes & Yes & Yes \\
Market in & Yes & & & & \\
equilibrium & & & & & \\
\hline
\end{tabular}

Note: $\mathrm{H}$-stat $=0$ indicates monopoly; $1<\mathrm{H}<1$ indicates monopolistic competition and $\mathrm{H}$-stat $=1$ indicates perfect competition.

${ }^{*} \mathrm{p}<0.05 ; * * \mathrm{p}<0.01 ; * * * \mathrm{p}<0.001$ 


\section{Figure 1}

\section{HHI of commercial banks by total assets}

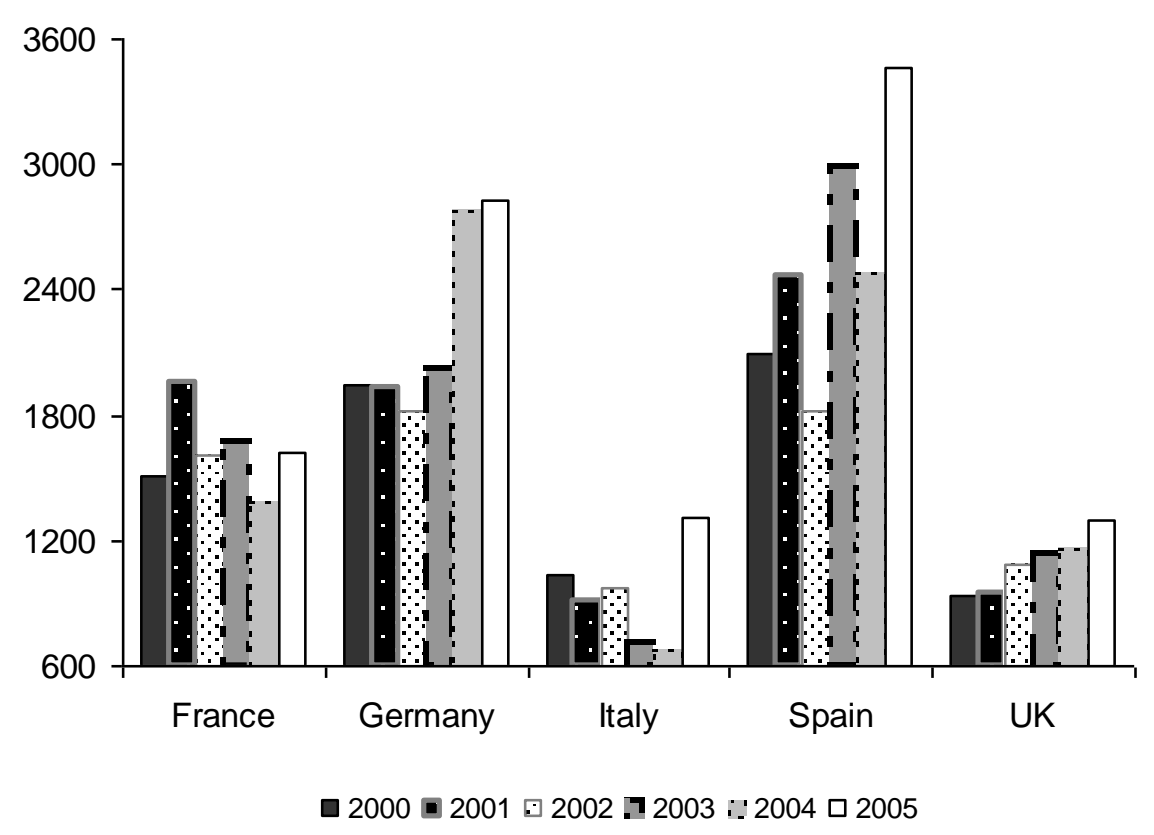




\section{Notes}

[1] Council Regulation (EC) No 139/2004 of 20 January 2004 on the control of concentrations between undertakings. Previous merger cases were dealt with either the "old" Council Regulation (EEC) No 4064/89, as last amended by Council Regulation (EC) No 1310/97; and those dealt with under Article 66 of the former Treaty establishing the European Coal and Steel Community (ECSC Treaty).

[2] Under this rule, national authorities cannot carry out a competition review where the Commission has jurisdiction, and a decision by the Commission covers the whole EU.

[3] See Dick and Hannan (2009) for more details and a comparison with the US system.

[4] Sector Inquiry under Art 17 of Regulation 1/2003 on retail banking - COM(2007)33 final.

[5] The industrial organisation literature evolved to account for this possibility. See Demsetz (1973); Smirlock (1985); Evanoff and Fortier (1988); Berger (1995).

[6] Data were collected for an unbalanced sample of 2,701 commercial bank observations operating in France, Germany, Italy, Spain and the United Kingdom between 2000 and 2005. An unbalanced panel allows us to account for mergers and acquisitions, entry and exit during the period. We use data from consolidated accounts, where available, to avoid double-counting. The data were analysed for inconsistencies, reporting errors, missing values and outliers.

[7] For example, until 2005 the German Landesbanks benefited state guarantees that have secured the high ratings and have given them access to cheap funding.

[8] For details on the estimation of the Lerner monopoly power see, among others, Shaffer (1993); Berg and Kim (1994); Angelini and Cetorelli (2003); and Fernandez de Guevara et al. (2005).

[9] For more details on the derivation of the Rosse-Panzar H-statistic see, among others, Goddard et al. (2001); Bikker and Haaf (2002); Casu and Girardone (2006).

[10] F-Test results indicate that the both hypothesis $\mathrm{H}$-stat $=0$ (monopoly) and the hypothesis $\mathrm{H}$-stat $=1$ (perfect competition) are rejected in all countries. Therefore the hypothesis of $1<\mathrm{H}<1$ (monopolistic competition) holds in countries.

[11] Under the assumption of constant elasticity of demand across markets, the model specification is consistent with a continuous interpretation of $\mathrm{H}$ and thus the comparison between countries is acceptable. 
[12] See, among others, Molyneux et al. (1994); De Bandt and Davies (2000); Bikker and Haaf (2002), Claessen and Laeven (2004); Casu and Girardone (2006).

[13] The equilibrium test can be performed by re-calculating the Panzar and Rosse's Hstatistics replacing the dependent variable total revenue over assets with the natural log of return on assets (which is equal to net income over total assets), as shown in equation (2). The findings will be interpreted as follows: $\mathrm{H}<0$ would indicate disequilibrium and $\mathrm{H}=0$ would indicate equilibrium (see Shaffer, 1982; Molyneux et al., 1994; Claessens and Laeven, 2004). 